\title{
FIBER QUALITIES OF PRETREATED BETUNG BAMBOO (Dendrocalamus asper) BY MIXED CULTURE OF WHITE-ROT FUNGI WITH RESPECT TO ITS USE FOR PULP AND PAPER
}

\author{
Widya Fatriasari ${ }^{1}$, Ratih Damayanti ${ }^{2}$ and Sita Heris Anita ${ }^{1}$ \\ Received : 10 December 2012, Accepted : 28 October 2013
}

\begin{abstract}
Previous research on anatomical structures of pretreated betung bamboo (Dendrocalamus asper) using single culture of white-rot fungi has been investigated, which revealed that the pretreatment caused the decrease in the Runkel ratio as well as the coefficient rigidity and the increase in the flexibility ratio of their corresponding bamboo fibers. However, there is no study reported on the anatomical structure changes of them caused by pretreatment using mixed culture of white-rot fungi. This paper reports the results of the research on paper and pulp quality after different treatments. Pretreatment that used Trametes versicolor fungi and lasted for 45 days inflicted intensive fiber damages compared with those of untreated bamboo (control). Fresh and barkless betung bamboo chips of 2 year's old, and $1.6 \mathrm{~cm}$ in length, were inoculated by $10 \%$ of mixed culture of white-rot fungi inoculums stock for 30 and 45 days in room temperature. There were four treatment groups of mixed culture, i.e T. versicolor and P. ostreatus (TV PO); P. ostreatus and P. chrysosporium (POPC); P. chrysosporium and T.versicolor (PCTV); and P.chrysosporium, T.versicolor and P.ostreatus (TVPCPO). After the inoculation period, the chips were macerated into separate fibers using Scultze method to analyze the fiber dimension and its derived values. The fibers were then observed regarding their macro and microscopic structures by optical microscope. Mixed culture pretreatment of white-rot fungi accelerated improvement of fiber morphology and fiber derived value characteristics, except for Muhlsteph ratio. The fiber derived values of treated bamboo tended to improve compared to those of untreated bamboo, there by requiring milder pulping conditions. Accordingly, the treated bamboo would indicatively produce a good quality pulp (grade I) based on FAO and LPHH (Forest Product Research Report) requirements. Co-culture treatment using P. chrysosporium and P. ostreatus for 45 days produced the best fiber dimension and its derived value properties. The fungi hypae colonized on the surface area of bamboo followed by mycelium penetration into substrate (bamboo-inner structure). The partial degradation caused by delignification indicatively attributed to the fungi activity was shown in the macroscopic images.
\end{abstract}

Keywords: Betung bamboo, mixed culture, white rot fungi, fiber dimension, fiber-derived value

\section{INTRODUCTION}

Bamboos typify as plants belonging to graminae, which afford very efficient photosynthesis ability as shown by the high production of ligno-cellulosic biomass (20-40 tons/ha/year), and this production is about 7 $30 \%$ higher than that of woody plants (Kant, 2010). These lignocellulosic materials as commonly produced by spermatophyta or (seed-

\footnotetext{
Research \& Development Unit for Biomaterials LIPI-Cibinong Jl. Raya Bogor KM 46 Cibinong Bogor 16911

2 Center for Forest Products Research and Development, Jl. Gunung Batu 5, Bogor 16000

Corresponding Author: widya_fatriasari@yahoo.com
}

bearing) plants (including woody softwood, woody hardwood, and bamboo monocot) are widely used for the production of pulp and paper, fiberboard, textile, food, methane, lactic acid, construction materials, reinforced fiber, bioenergy, bio-bleaching, enzyme, feed, enzymatic hydrolysis (Tsuda et al.,1998; Scurlock et al., 2000, Lee et al., 2001; Kobayashi et al., 2004; Vu et al., 2004; Isroi et al., 2011). The fast-growing woody plant species can be harvested after 8-20 years, while the harvesting period for bamboo is only 4 years (Nasendi, 1995). The previous study reported that betung and yellow bamboos afforded better fiber quality in terms of pulp and paper utilization (Fatriasari and Hermiati, 2008). 
The lignin content of the lignocellulose materials for pulp and paper is undesirable therefore it should be substantially reduced to particular level before utilizing it by using either conventional or non conventional processes Recently, biological pretreatment that included non-conventional approach is more interesting concurrent with the increasing concerns of environmental impacts. In the biological pretreatment of the lignocellulosic materials, white-rot fungi are utilized to split the complex bond of cellulose-lignin by extraction or decomposition of the lignin (Zadrazil et al., 1999). These fungi are known micro organisms being able to remove the lignin efficiently from plant cell walls (Haakala et al., 2005; Akhtar et al., 1998). These fungi secrete the lignolytic enzymes that penetrate into the plant tissues and further perform the degrading action on the lignocellulosic substrate (Messner and Srebtonik, 1994; Kirk et al.,1980). In metabolizing (e.g. depolimerizing and breaking down) the lignin polymers, a few of the white-rot fungi also unavoidably degrade the carbohydrate polymer in plant tissues (Blanchette, 1991; Istek, 2006). Thorough selection (screening) of white-rot fungi which has high delignification selectivity was an important step to improve the high yield in biopulping process.

In general, single culture of white-rot fungi in liquid inoculums is commonly used in the biological pretreatment of lignocellulosic materials. Cereperiopsis subvermispora is a well known fungus that has high delignification selectivity in many solid substrates, but this fungus did not grow well on betung bamboo. The other fungi such as Trametes versicolor, Phanerochaete chrysosporium, Pleurotusostreatus, Schizophylum commmune have been applied both in single culture inoculums using bamboo as substrate (Fatriasari et al., 2011,2009; Falah et al., 2010; Fitria et al., 2012), and in mixed culture inoculums (Fatriasari al., 2010), prior to chemical and semi-chemical pulping. The other lignocellulosic substrates such as rice straw (Ermawar et al., 2006), bagasse (Fitria et al., 2007; Anita et al., 2011 a, b; Fajriutami et al., 2011, 2012), oil palm empty fruit bunch (OEFB) (Risanto et al.,
2012), aspen wood (Chi et al., 2007) were also studied using single culture and mixed culture of three kinds of fungi for ethanol production. In addition combination of white-rot fungi ( $P$. chrysosporium) with brown-rot fungi (Fomitopsis polustris) had already been conducted to improve microwave performance and enzymatic hydrolysis action too (Fatriasari and Anita, 2012a,b). Investigation regarding to the effect of morphological and anatomical characteristics, after single culture inoculums pretreatment, on betung bamboo had already been done (Fatriasari et al., 2012). Meanwhile, their possible changes after mixed culture inoculums pretreatment unfortunately have not been reported yet.

In wood and many other micro structure environments, fungi are commonly living and growing in a symbiotic system or in an interaction. Mixed fungi cultures could lead to a higher enzyme production through synergistic interactions, but the final result seems to depend on the combination of the used particular fungi species, the mode of interaction between species, and the micro structure environments or nutritional conditions in the lignocellulosic substrate under colonization (Gutierrez-Correa and Tengerdy, 1997 in Chie et al., 2007). The previous study employing mixed culture of white-rot fungi pretreatment on betung bamboo, which was later pulped using alkali process, showed that the co-culture of two white-rot fungi species produced pulp with better pulp properties, compared to the properties of pulp from corresponding bamboo, which was pretreated with the mixing of three fungi inoculums. The best synergetic interaction was found on co-culturing $P$. chrysosporium and $T$. versicolor inoculums for 45 days. This study was conducted to investigate the possible pattern changes in anatomical and morphological characteristics of betung bamboo, attributed to the mixed fungi culture pretreatment.

\section{METHODOLOGY}

\section{A. Preparation of materials}

Fresh, bark-less of 2 years old betung bamboo (Dendrocalamus asper), originating from 
Nanggewer, Cibinong was cut to smaller sizes using a drum chipper and hammer-mill to obtain bamboo chips of about $\pm 1.6 \mathrm{~cm}$ in length. The chips were then stored in a refrigerator to avoid microorganism contamination. Afterwards, they were kept for 24 hours at room temperature, and then sterilized in an autoclave for 45 minutes at $121^{\circ} \mathrm{C}$ before fungi application.

\section{B. Biological pretreatment}

Trametes versicolor, Phanerochaete chrysosporium and Pleurotus ostreatus fungi inoculums were separately cultured on malt extract agar (MEA) slant (10.65 grams of MEA in $300 \mathrm{ml}$ aquades) for 7-14 days. Five ml of the JIS (Japan Industrial Standard) broth medium, which was made by adding $3 \mathrm{~g} \mathrm{K \textrm {K } _ { 2 }} \mathrm{PO}_{4}$, $2 \mathrm{~g} \mathrm{MgSO}_{4} \cdot 7 \mathrm{H}_{2} \mathrm{O}, 25 \mathrm{~g}$ glucose, $5 \mathrm{~g}$ peptone, and $10 \mathrm{~g}$ malt extract into $1 \mathrm{~L}$ of aquades, was injected intoevery14 days by cultured fungi and then scratched by ose. The suspension of fungi was then poured into $95 \mathrm{ml}$ of JIS broth medium and incubated at $27^{\circ} \mathrm{C}$ for $7-8$ days. After incubation, 10 gram of corn steep liquor was then poured into $100 \mathrm{ml}$ of fungi inoculums. They were then homogenized by a high speed warring blender twice, each for 20 seconds. The obtained homogenized solution was used as inoculum stock.

The air dry bamboo chips, equivalent to their oven dried weight (ODW) of $250 \mathrm{~g}$, were put into heat-resistant plastic bag. There were four treatment groups namely, (1) mixed inoculum stock of $P$. ostreatus and T. versicolor (designated as TVPO); (2) mixed inoculum stock of P. ostreatus and P. chrysosporium (as POPC); (3) mixed inoculum stock of $P$. chrysosporium and $T$. versicolor (as TVPC); and (4) mixed inoculum stock of $P$. ostreatus, T. versicolor and P. chrysosporium (as TVPCPO). $25 \mathrm{ml}$ of each liquid inoculum stock was injected into bamboo chips and then those were incubated in room temperature of $29-30^{\circ} \mathrm{C}$ for 30 and 45 days. After the incubation, part of the samples was treated with maceration process to determine the anatomical characteristics.

\section{Fiber characteristics}

For examining the characteristics of bamboo fibers, the bamboo samples should be initially macerated. The procedures for maceration were similar to those commonly employed for other lignocellulosic fibers, in accordance with the socalled Schultze method (Sass, 1961). As such, the bamboo sample were heated slowly to $50-60^{\circ} \mathrm{C}$ in the mixture of concentrated acetic acid and hydrogen peroxide $\left(\mathrm{H}_{2} \mathrm{O}_{2}\right)$ at a ratio of 1:1. The heating process took 12-24 hours to ensure the complete separation of fiber-to-fiber (interfiber) bonds or other lignocellulosic tissues into individual cells. The separated fibers were afterwards washed by water, and then were colored by safranin-O. To examine the fiber dimensions, the separated cells were placed on the object glass; ethanol-glycerin was then added, and the cells were evenly spread using a coarse needle before closing the object glass with cover glass. The sample was then ready for microscopic observation to measure the fiber dimensions of both the fungi-pretreated bamboo as well as the untreated bamboo (as control).

Fiber dimensions measured included fiber length, lumen diameter, fiber diameter, and cellwall thicknesses. The measurement for fiber length was performed 30 times, while for diameters and thicknesses 15 times to obtain their average values. The values of fiber dimensions were then used to calculate their derived values of Runkel ratio, felting power, Muhlsteph ratio, coefficient of rigidity and flexibility ratio. In addition, the macroscopic and microscopic characteristics of the intact bamboo tissues (not macerated) were also observed using optical microscope. Such observation was performed by viewing the cross-sectional characteristics of bamboo sample to obtain the microscopic features of its tissues.

\section{RESULT AND DISCUSSION}

Fiber dimension and its derived value are important indicators to predict the traits of the resulting pulp and paper. Fiber length of treated bamboo was up to $2 \mathrm{~mm}$ (Table 1), and therefore it was categorized as long-fiber and it was judged as grade-I based on the criteria for Indonesia's woods as raw materials for pulp and paper. Compared with the untreated bamboo, fiber length of the treated samples tended to decrease. It might be related to the activity of the white-rot 
fungi (WRF) which degraded easily accesible hemicellulose over cellulose to provide nutrient for supporting its growth and methabolism and left the cellulose (Yu et al., 2009). The mycelium grew first on the outside and followed by inside penetration of the strand layer. Partial removal of lignin and hemicellulose destroyed the carbohydrate-lignin complex leading to the disruption of the hydrogen bond between cellulose, thus fibrillation occurred (Li et al., 2010). WRF treatment could intensify the lignin degradation in bamboo through their ligninolytic enzyme activity (Mosai et al., 1999; Bjapai et al., 2004). This ligninolytic enzyme influenced the changes of anatomical characteristics of bamboo cells. Both the fiber and lumen diameters after WRF pretreatment became wider, while cell wall thickness was thinner. The thin cell-wall will affect positively the flexibility of fibers by providing the broader contact-surface area for inter fiber bonding. The decreasing of cell wall thickness has been predicted, it was caused by the enzyme activity that depolymerize the lignin structure of bamboo cell wall. The lignin fragmentation led to decrease in the lignin content of the bamboo. The widest and narrowest lumen diameter of bamboo cells occurred following the consecutive pretreatment with POPC for 45 days and with TVPO for 30 days, respectively (Table 1). Coculture of both POPC and TVPO showed the most intensive activity as indicated by the substantial decrease in bamboo cell-wall thickness. A thick cell wall causes formation of rough and thick paper sheet with high tear strength, but the tensile and folding strengths were predictably low. A thick fiber-wall tends to maintain its rigid and round shape during the sheet formation. This situation can complicate the fibrillation process during the beating/refining actions of lignocellulosic fibers (Casey, 1980). The lower inter fiber bonding between fibers with thick cell wall is caused by two reasons. First, the paper sheet is formed on the weight basis, therefore the number of fibers in the sheet (as retained on the forming wire) is inversely proportional to the density of the cell wall; and second, a thick cell wall has a smaller surface area per weight unit than thin cell wall. Accordingly, the fibers with thick cell wall explain their small possibility to form perfect inter fiber bonding (Haygreen and Bowyer, 1996).
In general, fungi pretreatment resulted in as light decrease in bamboo fiber length, as compared to that of untreated bamboo (control) (Table 1), and therefore were categorized as longfiber. Further, the fiber length of pretreated bamboo by PCPO for 45 days exhibited the highest value; mean while the TVPC pretreatment for 30 days produced the lowest value in fiber length (Table 1). It means that co-culture of TVPC for 30 days indicatively performed the most intensive delignification activity. A long fiber will enhance its flexibility and provide better fiberentanglement and greater contact-surface area, and therefore accelerate a better inter fiber bonding formation through hydrogen bond in the paper forming process. Therefore, the longer the fiber, the better the paper properties. The fiber length and fiber derived value such as flexibility ratio affected positively the tear, tensile index and folding endurance (Pasaribu and Tampubolon, 2007). The tear strength is strongly influenced by fiber length and directly related until the fiber length reaches 4-5 mm. A good inter fiber bonding causes a formed paper-sheet with high tear strength and impenetrable to light (Haygreen and Bowyer, 1996). Long fiber also produces the sheet with higher tear strength, as it is related to the formation of the fiber-to-fiber bonding of the wider contact-surface area than short fiber (Syafii and Siregar, 2006). A better inter fiber bonding can be potentially provided by lignocellulosic stuffs with long fiber (Abubakar et al., 1995) Long fiber in pulp and paper can improve tear strength of paper (Hubbe and Heitmann, 2007).

White-rot fungi not only produce a whole set of enzymes for lignin degradation but also can act as a transporter for these enzymes into the wood flakes, which further can change the psychological conditions required for enzymatic reaction (Islam et al., 2007). T. versicolor produces enzymes such as manganese peroxidase (MnP), laccase, hemicellulase, and cellulose (Yang et al., 2007). These enzymes use low molecular weight mediator to attack lignin (Perez et al., 2002). Lobos et al. (2001) and Hossain and Anantharaman (2006) mentioned that P. ostreatus and T. versicolor produce 3 types of lignolytic enzymes, i.e. laccase, lignin peroxidase (LiP), and manganese peroxidase. LiP, has the structural difference from that of $\mathrm{MnP}$ in the ability to oxidize chemical bonds in lignin. On the other hand, MnP degrades 
lignin indirectly by providing $\mathrm{H}_{2} \mathrm{O}_{2}$ for the bioreaction of lignin with peroxidase (Hossain and Anantharaman, 2006). These enzymes were discovered in P. chrysosporium was MnP (Kirk and Chang, 1990). LiP demonstrated the ability to oxidize the lignin bond. In contrast, MnP degrades lignin indirectly by providing $\mathrm{H}_{2} \mathrm{O}_{2}$ for precursors (Kirk and Chang, 1980; Hossain and Anantharaman, 2006).

There were three possible interactions between the funguses. i.e. (1) antagonistic interaction that produces more rapid exploitation of nutrition, parasitism, (2) other forms of interaction deadlock which are typically no fungal hypae that penetrate into the substrate; and (3) synergistic interaction in which the fungi play a role in the interaction of degrading the same substrate (Boddy, 2000). Therefore, the phenomenon of the decreased fiber length, cell wall thicknesses as well as the increased lumen and fiber diameter might occur where the species of fungus act synergistically/mutualistically.

The requirements of the ligno-cellulosic fiber as raw material for pulp and paper with respect to fiber dimension and its derived values, and the results of bamboo-fiber scoring based on its fiber dimension/derived value are presented in
Table 2. The pulp and paper properties are also influenced by fiber derived values. These values/parameters mostly affect the physical properties of the paper sheet. As an example, Runkell ratio is the ratio of the cell wall thickness to lumen diameter, where the value/ratio less than or equal to one is considered very good for the paper.

Fibrillation can be used to improve fiber-tofiber contact. A high Runkel ratio indicates that fibers are more resistant to external forces (milling, pressing and drying), and they are harder to form into paper sheet. Pretreated bamboo by mixed culture of WRF showed a good fiber derived value, and the pulp quality was judged as grade I based on FAO and LPHH criteria with the total score of 525. There was no significant difference in fiber derived values between treatment combinations (mixed culture) of WRF. It means that the treated bamboo materials will predictably produce pulp and paper with good satisfactory properties.

In comparison with the untreated bamboo samples (Fatriasari and Hermiati, 2008), all treatments with fungi caused positive effect in decreasing the Runkell ratio and the coefficient of rigidity, as well as increasing the flexibility ratio.

Table 1.Values of bamboo-fiber dimensions

\begin{tabular}{|c|c|c|c|c|c|c|c|c|c|}
\hline \multirow{2}{*}{ Discription } & \multicolumn{8}{|c|}{ Mixed inoculum of white-rot fingi species / Incubation days } & \multirow[b]{2}{*}{ Control: } \\
\hline & TVPC & POPC & TVPO & TVPCPO & TVPC & POPC & TVPO & TVPCPO & \\
\hline $\begin{array}{l}\text { Fiber } \\
\text { dimensions }\end{array}$ & \multicolumn{4}{|c|}{30 days } & \multicolumn{4}{|c|}{45 days } & \\
\hline $\begin{array}{l}\text { Piber } \\
\text { Length/L }(\mathrm{mm})\end{array}$ & 3.51736 & 3.87926 & 3. 83307 & 3.5844 & 3.89971 & 4.10329 & 3.65865 & 3.78048 & 4.693 \\
\hline $\begin{array}{l}\text { Grade } \\
\text { Piber }\end{array}$ & 1 & 6 & 5 & 2 & 7 & 8 & 3 & 4 & \\
\hline $\begin{array}{l}\text { Diameter } / \mathrm{d} \\
(\mathrm{mm})\end{array}$ & 0.02900 & 0.031230 & 0.02928 & 0.031232 & 0.02955 & 0.03072 & 0.02968 & 0.029488 & 0.025 \\
\hline $\begin{array}{l}\text { Grade } \\
\text { Lumen }\end{array}$ & 1 & 7 & 2 & 8 & 4 & 6 & 5 & 3 & \\
\hline $\begin{array}{l}\text { diameter/e } \\
(\mathrm{mm})\end{array}$ & 0.024528 & 0,026368 & 0.024416 & 0.026368 & 0.024896 & 0.026464 & 0.025392 & 0.024896 & 0.007 \\
\hline $\begin{array}{l}\text { Grade } \\
\text { cell wall }\end{array}$ & 3 & 6 & 2 & 7 & 4 & 8 & 5 & 4 & \\
\hline $\begin{array}{l}\text { thickness } / \mathrm{w} \\
(\mathrm{mm})\end{array}$ & 0.00224 & 0.002432 & 0.002432 & 0.002432 & 0,002328 & 0.002128 & 0.002128 & 0.002296 & 0.009 \\
\hline Grade & 7 & 4 & 4 & 4 & 5 & 8 & 8 & 6 & \\
\hline Score totzl & 12 & 23 & 13 & 21 & 20 & 30 & 21 & 17 & \\
\hline R.nk & 7 & 2 & 6 & 3 & 5 & 1 & 3 & 4 & \\
\hline
\end{tabular}

Remark: 1) Source: Fatriasari and Hermiati, 2008; TVPC stands for the mixed inoculum stock of P. chrysosporium and T. versicolor, POPC for that of P. ostreatus and P. chrysosporium; TVPO for that of P. ostreatus and T. versicolor, and TVPCPO P. ostreatus, T. versicolor and P.chrysosporium 
Such occurring phenomena (decrease/increase) were affected by both the thinner cell wall and wider cell diameter, due to fungi action. This result is in line with our previous study on single culture pretreatment of betung bamboo (Fatriasari et al., 2012). This condition will enable bamboo pulp to form a paper sheet with high tensile index. Flexibility ratio is the ratio of fiber length to the fiber diameter, whereby this ratio reveals a parabolic-shaped correlation with the paper tensile index and breaking length (Pasaribu and Silitonga, 1974 in Utama, 1995). Further, the factors that affect the paper tensile strength are the intensiveness/quality of inter fiber bonding, extents of pulp fibrillation, presence of fines/ degraded fibers, and amount of fillers (Elyani et al., 2011). Lignocellulosic fibers with high flexibility produce paper with good breaking length, un-rigid (flexible) fiber properties, and high tensile strength.

Coefficient of rigidity is the ratio between cell wall thickness and fiber diameter. This coefficient was expected to have a negative correlation with tensile strength of paper. Almost all of the pretreated bamboos gave pulp with lower coefficient of rigidity. There is a sharp decline in this coefficient/value compared with that of untreated bamboo (Fatriasari and Hermiati, 2008). Such favorable phenomena could occur on pretreated bamboo with mixed culture of WRF, as it resulted in the thinning of the cell-wall thickness and the widening of fiber diameter. On the other hand, the longer incubation period tended to decline the value of rigidity coefficient. This can be understood as the longer the period, the more intensive the depolymerization of lignin structure, rendering the bamboo fiber less rigid (un-rigid). Un-rigid fibers can provide better fiber-to-fiber bonding, thereby yielding paper sheet with good qualities of internal bond.

The ratio of lumen diameter to fiber diameter can be expressed as felting power/slenderness. The higher the ratio, the better the formation of inter fiber bonding in the paper sheet (Rhamdani, 1994). The fibers of the treated bamboo apparently had loose arrangement, thereby predictably giving paper sheet with lower tear index. A sharp increase in Muhlsteph ratio occurred to all fibers of pretreated bamboo; however the longer incubation time tended to decrease such ratio regardless of kinds/species of fungi. The lower Muhlstep ratio usually leads to the lowering of folding-endurance of pulp/paper sheet (Rhamdani, 1994), and therefore causes unsatisfactory quality of the product. Tear strength of the pulp/paper is closely related to the felting power of the fiber, that is the higher the power the greater the tear strength. Intensive as well as perfect interfiber bonding produces paper sheet with high tear strength and density (Haygreen and Bowyer, 1996). Considering the convenient derived values of treated bamboo fibers with the four co-culture treatments, i.e. TVPC, POPC, TVPO, and TVPCPO (Tables 1 and 3), expectedly this enables the treated bamboo fibers to produce paper sheet with high breaking length up to a particular extent. This is because, based on previous experiment, there is a parabolic-shaped correlation between those derived values and breaking length. Further more, flexibility ratio is the ratio of lumen diameter to fiber diameter, whereby the higher the ratio the bigger the lumen diameter and smaller the fiber diameter. Lignocellulosic fibers with higher flexibility ratio can provide greater breaking length for the paper sheet.

Based on this scoring data of bamboo fibers, bamboo pretreated by POPC for 45 days incubation exhibited the most-convenient fiber dimension and fiber derived values (Tables 1 and 3) with its score reaching 63.

The study reported by Fatriasari et al. (2010), showed that TVPC pretreatment for 45 days, prior to the kraft pulping produced the pulp with the best properties. Besides, the co-culture using two kinds of WRF provided pulp with better performance than the mixing of three kinds (species) of fungi inoculums into the bamboo-fiber-containing substrate, although its fiber derived value did not achieve the best score. In this study, inoculum mixing of PC, TV and PO also showed good anatomical properties. It indicated that pulp properties were affected by the employed pulping condition.

The figure below show the macroscopic and microscopic images of bamboo tissues under white-rot fungi treatment. The image indicates that the degradation patterns as occurred were caused by fungi activity in the substrate $(\mathrm{A}-\mathrm{H})$. 


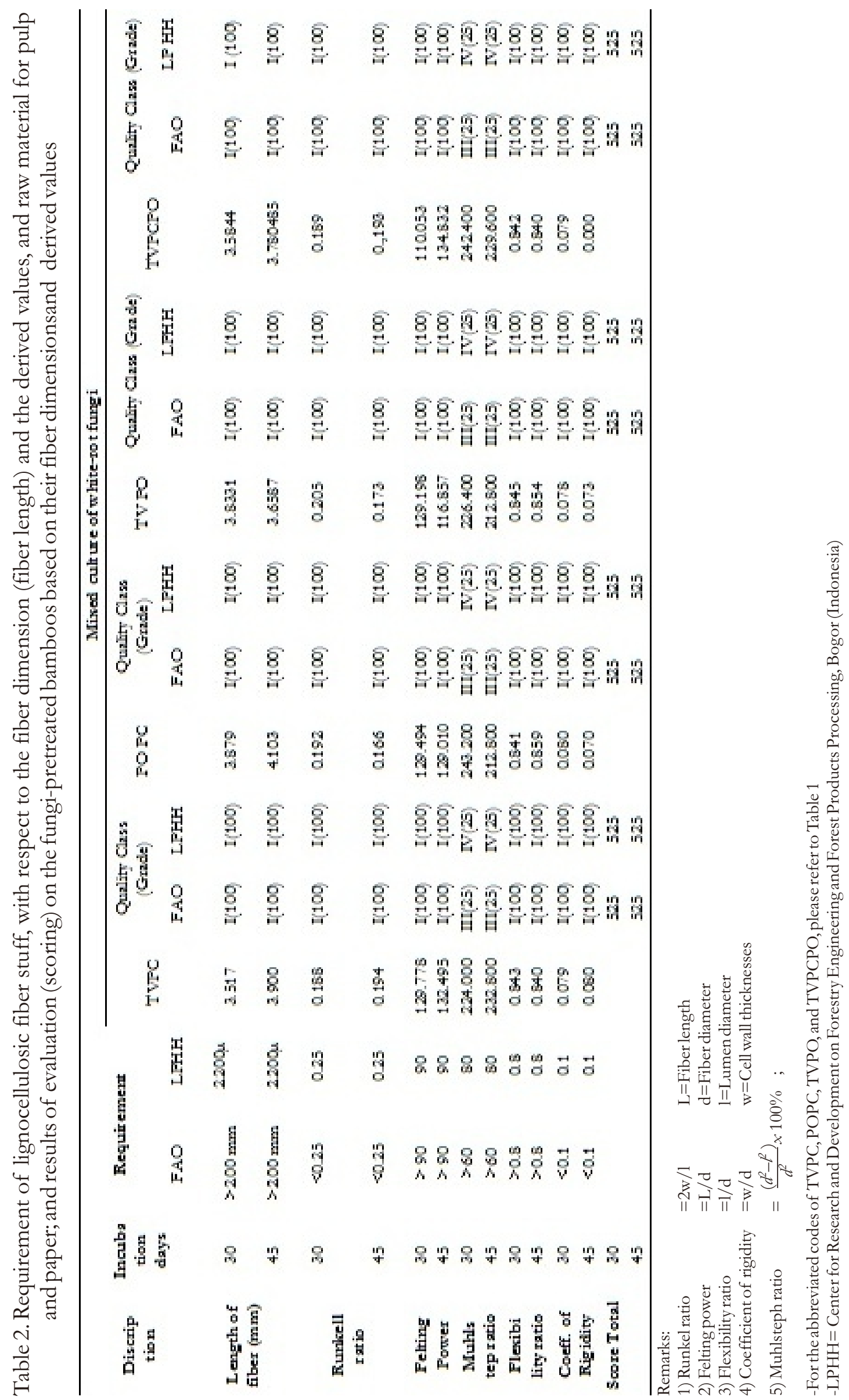


Table 3. Summary of scoring of fiber dimension's derived values for fungi-pretreated bamboo

\begin{tabular}{|c|c|c|c|c|c|c|c|c|c|}
\hline \multirow{2}{*}{\multicolumn{2}{|c|}{$\begin{array}{l}\text { White rot fungi } \\
\text { tres tment }\end{array}$}} & \multirow{2}{*}{$\begin{array}{c}\text { Incubation } \\
\text { periods } \\
\text { (days) }\end{array}$} & \multicolumn{5}{|c|}{ Fiber derived value } & \multirow{2}{*}{$\begin{array}{l}\text { Scare } \\
\text { Total }\end{array}$} & \multirow{3}{*}{ R.ank } \\
\hline & & & Runkell & Felting & Muhlstep & Plexibility & Coeff. & & \\
\hline \multirow{8}{*}{$\begin{array}{l}\text { Mired } \\
\text { culture }\end{array}$} & \multirow{2}{*}{ TVPC } & 30 & 6 & 6 & 7 & 5 & 5 & 29 & \\
\hline & & 45 & 2 & 7 & 3 & 2 & 4 & 18 & 4 \\
\hline & \multirow{2}{*}{ POPC } & 30 & 4 & 5 & 1 & 3 & 8 & 21 & 5 \\
\hline & & 45 & 8 & 3 & 8 & 8 & 6 & 33 & 1 \\
\hline & \multirow{2}{*}{ TVPO } & 30 & 1 & 4 & 6 & 6 & 4 & 21 & 5 \\
\hline & & 45 & 7 & 2 & 8 & 7 & 7 & 31 & 2 \\
\hline & \multirow{2}{*}{ TVPCPO } & 30 & 5 & 1 & 2 & 4 & 5 & 17 & 3 \\
\hline & & 45 & 3 & 8 & 6 & 2 & 4 & 23 & 4 \\
\hline
\end{tabular}

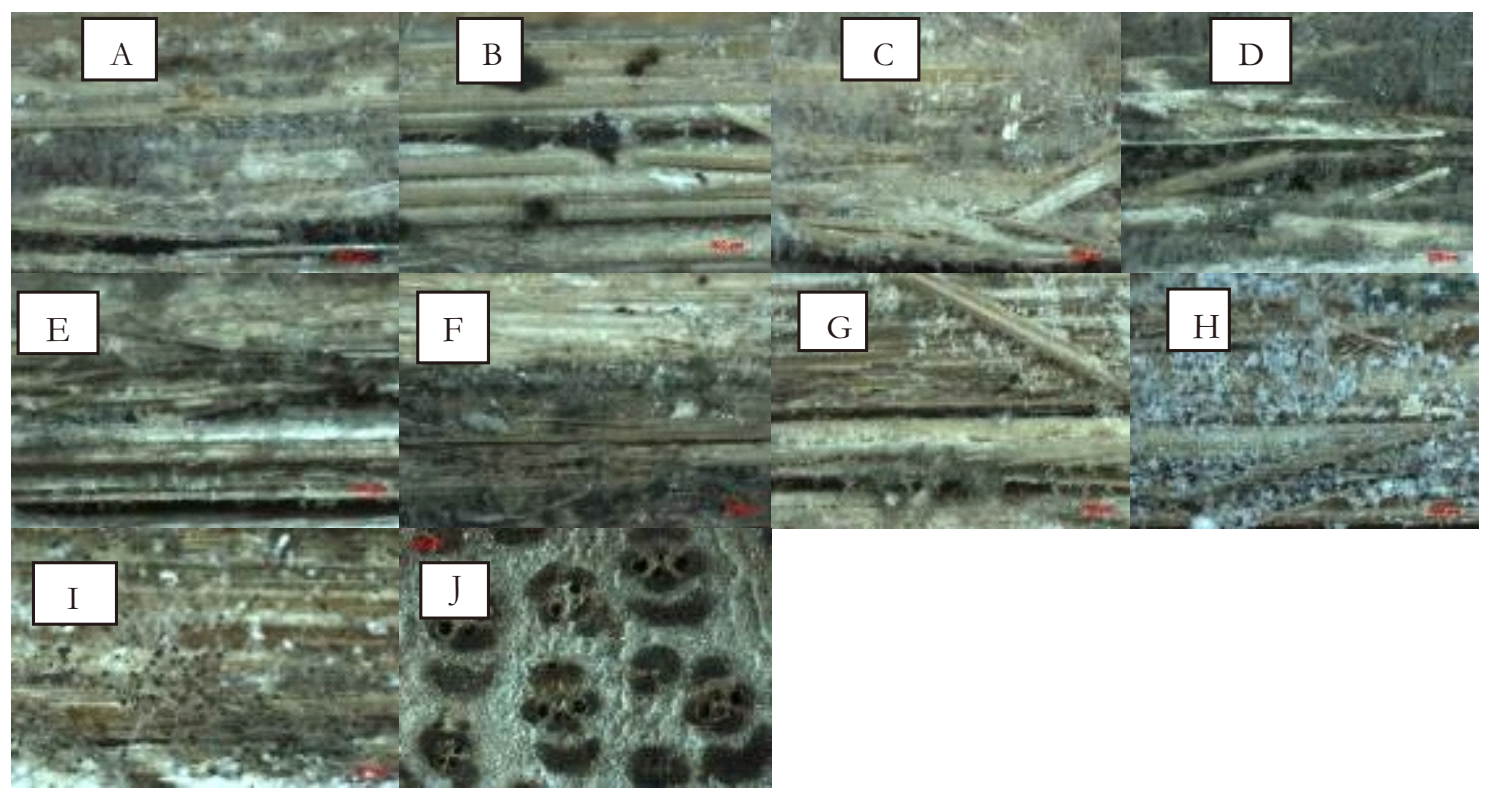

Figure 1. Microscopic image of pretreated bamboo by P. ostreatus and P. chrysosporium (POPC) 30 days (A), POPC 45 days (B), P.ostreatus and T. versicolor (POTV) 30 days (C), POTV 45 days (D), T.versicolor and P. chrysosporium (TVPC) 30 days (E), TVPC 45 days (F), T.versicolor, $P$. chrysosporium and $P$. ostreatus (TVPCPO) 30 days $(\mathrm{G})$, TVPCPO 45 days $(\mathrm{H})$, untreated bamboo (I), vascular bundle (J)

Fiber proportion per $\mathrm{mm}^{2}$ (Fatriasari et al., 2012) of bamboo tissue was dominated by parenchyma cells $(65.18 \%)$, followed in decreasing order by fiber cells $(31.85 \%)$ and metaxylem tissues $(1.44 \%)$. A high parenchyma cell proportion tended to produce pulp with lower yield. The fungi secreted the hyphae to penetrate into the cell wall via bamboo surface. Macroscopic vascular bundle of untreated bamboo can be seen in images A-J. This bundle has a function as food and water channel. These figures show that the fungi colonized the bamboo chips, degraded their cell walls and detached the fibers. Partial degradation of cell lumen walls was evident. Those studies showed that there seemed to be no substantial effect on bamboo cell walls or modification of cell wall within a relatively short time after inoculation, although the amount of lignin was not significantly removed. SEM (scanning electron microscope) images as reported by Fatriasari et al. (2010) showed that the degradation activity of WRF occurred on the substrate. Other studies on the microscopic level of the fungal growth patterns of P. chrysosporium 


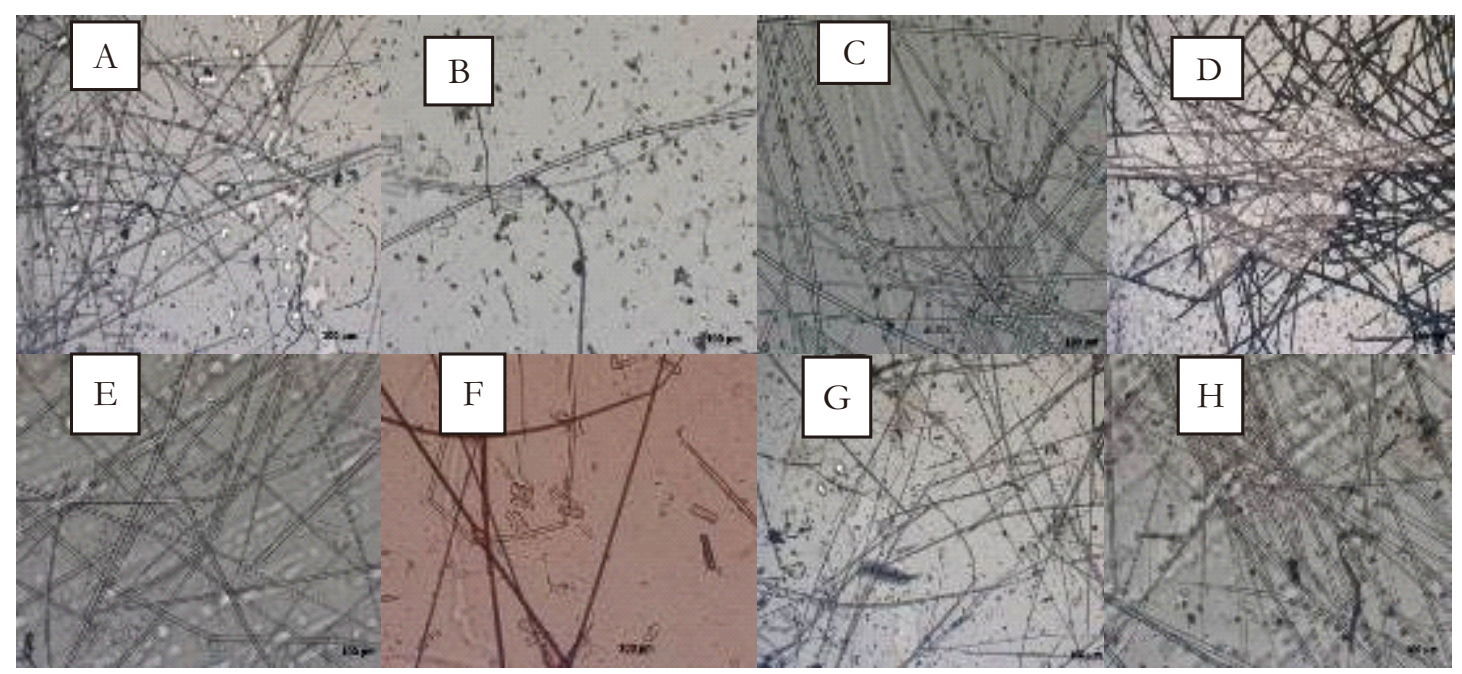

Figure 2. Microscopic image of pretreated bamboo fiber by P. ostreatus and P. chrysosporium (POPC 30 days (A), POPC 45 days (B), P. ostreatus and T. versicolor (POTV 30 days (C), POTV 45 days (D)), T.versicolor and P. chrysosporium (TVPC 30 days (E), TVPC 45 days $(\mathrm{F})$ ), T.versicolor, $P$. chrysosporium and P. ostreatus (TVPCPO 30 days (G), TVPCPO 45 days $(\mathrm{H})$ )

and C. subvermispora in aspen wood chips showed that $P$. chrysosporium grew well on both across the chip surfaces and throughout the cell wall. Degradation of cell wall possibly occurred. As such, the fungi might sustain the decolonization in all planes of the xylem tissue causing its decay, firstly via the vessels and later on via ray parenchyma. The decay captured the nutrient that was reserved within ray parenchyma and then colonized it to be distributed to the fungal mycelium throughout the sapwood. (Akhtar et al., 1998). Therefore, to clearly identify the changes on the cell walls degradation, further examination using the ultra-structural technique is necessary.

The maceration of mixed-culture-treated bamboo-fiber caused the bundles of fiber to separate through their common cell-wall into single (individual) fibers (Figure 2). The fungi degrading action that caused the physical damage to single bamboo fibers occurred mainly in pretreated bamboo by $T$. versicolor for 45 days (Fatriasari et al., 2012). However on the mixed culture fungi treatment, there seemed to be no significant difference in the effect among the mixed culture treatment on the fiber separation.

\section{CONCLUSION}

Implementation of mixed culture of various white-rot fungi species enhanced the performance of fiber morphology (i.e. fiber dimensions and their derived value). As such, there was a decrease consecutively in bamboo fiber length, cell wall thicknesses, while with respect to the fiber and its lumen diameter, the changes were on contrary. Compared to the untreated bamboo, all the fiber-dimensionderived values of the fungi-treated materials tended to improve (positively affecting the pulp and paper properties), except for Muhlsteph ratio. As such, the treated bamboo would indicatively require milder pulping condition, thereby lessening fiber degradation; and hence predictably producing a good quality pulp (grade I) based on FAO and LPHH requirements. The combination of P. chrysosporium and P. ostreatus treatment for 45 days provided the bamboo with the best fiber dimension and its derived values were most satisfactory. The white-rot fungi grew well on the bamboo substrate, and the corresponding fungi hypae were colonized on the bamboo-surface area followed by the mycelium penetration into the substrate. The evidence of this partial degradation in the fungi-treated bamboo caused by lignin depolymeri-zation (compared to the untreated bamboo) was shown by the related macroscopic images.

\section{REFERENCES}

Akhtar, M., Lentz, M. J., Blanchette, R. A., \& Kirk, T. 
K. (1997). Corn steep liquor lowers the amount of inoculum for biopulping. APPI Journal, 80(6), 161-164.

Anita, S. H., Fajriutami, T., Fitria, Ermawar, R. A., Yanto, D. H., \& Hermiati, E. (2011). Pretreatment Trametes versicolor dan Pleurotus ostreatus pada bagas untuk produksi bioetanol. Jurnal Teknologi Indonesia, 34(edisi khusus), 3339.

Bjapai, P., Bajpai, P. K., Akhtar, M., \& Jauhari, M. B. (2001). Biokraft pulping of eucalyptus with selected lignin degrading fungi. J. Pulp \& Paper Sci, 27(7), 235-239.

Blanchette, R. A. (1991). Delignification by wood decay fungi. Annu Rev Phytopathol, 29, 381-398.

Boddy, L. (2000). Interspesific combative interactions between wood-decaying basidiomycetes. FEMS Microbiology Ecology, 31, 185-194.

Chi, Y., Hatakka, A., \& Maijala, P. (2007). Can coculturing of two white-rot fungi increase lignin degradation and the production of ignindegrading enzymes? International Biodeterioration \& Biodegradation, 59, 2-39.

Elyani, N., Jenni, R., Wirawan, S. K., \& Cucu. (2011). Penanganan sticky and pitch secara enzimatis pada daur ulang kertas bekas. Jurnal Selulosa, 1(1), 15-19.

Fatriasari, W., \& Anita, S. H. (2012). Evaluation of two-stage fungal pretreatment for the microwave hydrolysis of betung bamboo. Proceeding of the $2^{\text {nd }}$ Korea-Indonesia Workshop on Bioenergy from Biomass Serpong, 13-15 Juni 2012. Pp95-100.

Fatriasari, W., \& Anita, S. H. (2012). Two-stage fungal preteatment for improved enzymatic hydrolysis of betung bamboo. The $12^{\text {th }}$ Science Council of Asia (SCA) Conference and Intenational Symposium Bogor, 10-12 July 2012.

Fatriasari, W., \& Hermiati, E. (2008). Analisis morfologi serat dan sifat fisis-kimia pada enam jenis bambu sebagai bahan baku pulp dan kertas. Jurnal Ilmu dan Teknologi Hasil Hutan, 1(2), 67-72.

Fatriasari, W., Damayanti, R., \& Anita, S. H. (2012). Anatomical structure changes of betung bamboo pretreated by white rot fungi. The $5^{\text {th }}$ Indonesian Biotechnology Conference An InternationalForum, $4^{\text {th }}-7^{\text {th }}$ of July 2012.

Haygreen, J. G., \& Bowyer, J. L. (1996). Hasil hutan dan ilmu kayu: suatu pengantar. Yogyakarta: Gajah
Mada University Press.

Hossain, S. K., \& Anantharaman, N. (2006). Activity enhancement of ligninolytic enzymes of Trametes versicolor with bagasse powder. African Journal of Biotechnology, 5(1), 189-194.

Hubbe, M. A., \& Heitmann, J. J. (2007). Review of factors affecting the release of water from cellulosic fibers during paper manufacture. Bioresources, 2(3), 500-523.

Islam, M. N., Karim, M. R., \& Malinen, R. O. (2008). Beneficial effects of fungal treatment before pulping and bleaching of Acacia mangium and Eucalyptus camaldulensis. Turk J Agric For, 32, 331338.

Isroi, Millati, R., Syamsiah, S., Niklasson, C., Cahyanto, M. N., Ludquist, K., et al. (2011). Biological pretreatment of lignocelluloses with white-rot fungi and its applications: a review. Bioresources, 6(4), 5224-5259.

Istek, A. (2006). Effect of Phanerochaetecrys sosporium white rot fungus on the chemical composition of Populus tremula L. Cellulose. Chemistr y and Technology, 40(6), 475-478.

Kant, P. (2010). Should bamboos and palms be included in CDM forestry projects? (IGREC Working Paper No. IGREC07:2010). New Delhi: Institute of Green Economy.

Kirk, T. K., \& Chang, H. M. (1990). Biotechnology in pulp and paper manufacture: Application and fundamental investigations. In T. K. Kirk, \& H. M. Chang (Ed.), Proceedings of the Fourth International Conference on Biotechnology in the Pulp and Paper Industry, (pp. 1-13).

Kirk, T. K., Higuchi, T., \& Chang, H. (1980). Lignin biodegradation microbiology, chemistry and potential application. (T. K. Kirk, T. Higuchi, \& H. Chang, Eds.) Boca Roton, USA: CRC Press Inc.

Kobayashi, F., Take, C., Asada, C., \& Nakamura, Y. (2004). Methane production from steamexploded bamboo. Journal of Bioscience and Bioengineering, 97, 426-428.

Lee, A. W., Chen, G., \& Tainter, F. H. (2001). Comparative treatibility of moso bamboo and southern pine with CCA preservative using a commercial schedule. Bioresource Technology, 77, 87-88.

Lobos, S., Tello, M., Polanco, R., Larrondo, L. F., Manubens, A., Salas, L., et al. (2001). Enzymology and molecular genetics of the ligninolytic system of the basidiomycetes 
Cereperiopsis subvermispora. Current Science, 81(8), 992-997.

Messner, K., \& Srebotnik, E. (1994). Biopulping: an over view of developments in an environmentally safe paper making technology. FEMS Microbiology Reviews, 13, 351-364.

Lobos, S., M. Tello, R. Polanco, L.F. Larrondo, A. Manubens, L. Salas and R. Vicuna. 2001. Enzymology and molecular genetics of the ligninolytic system of the basidiomycetes Cereperiopsis subvermispora. Current Science 81(8):992-997.

Nasendi, B. D. (1995). Bamboo for socio economic development and sustainable resource management: some research needs, the case of Indonesia. Paper prepared for IV International Bamboo Congress/Research Workshop, 19-22 June 1995 in Ubud, Bali, Indonesia. Bogor: Forest Products and Forestry Socio-Economic Research Development Center.

Pasaribu, R. A., \& Tampubolon, A. P. (2007). Status teknologi pemanfaatan serat kayu untuk bahan baku pulp. Paper presented on Workshop sosialisasi program dan kegi atan BPHPS guna mendukung kebutuhan riset hutan tanaman kayu pulp dan jejaring kerja.

Risanto, L., Anita, S. H., Fatriasari, W., \& Prasetyo, K. W. (2012). Biological pretreatment of oil palm empty fruit bunch fiber by mixed culture two white rot fungi. The 5th Indonesian Biotechnology Conference International Forum, 4 -7 of July 2012.

Sass, J. E. (1961). Botanical Microtechnique. Iowa: The IOWA State University Press.

Scurlock, J. M., Dayton, D. C., \& Hames, B. (2000). Bamboo: an overlooked biomass resources? Biomass and Bioenergy, 19(4), 229-244.

Syafii, W., \& Siregar, I. Z. (2006). Sifat kimia dan dmensi serat kayu mangium (Acacia mangium Willd) dari tiga provenans. Jurnal Ilmu dan Teknologi Kayu Tropis, 4(1), 29-32.

Tsuda, M., Aoyama, M., \& Cho, N. S. (1998). Catalyzed steaming as pretreatment for the enzymatic hydrolysis of bamboo grass culms. Bioresource Technology, 64, 241-243.

Utama, M. D. (1995). Pengaruh penambahan subu maksimum pemasakan dalam pembuatan pulp soda antrakinon dari limbah kelapa sawit (Elaeis guineensis Jacq.). Skripsi. Bogor: Fahutan IPB.

Vu, T. H., Pakkanen, H., \& Alen, R. (2004).
Delignification of bamboo (Bambusa roceraacher) Part 1. Kraft pulping and the subsequent oxygen delignification to pulp with a low kappa number. Industrial Crops and Product, 19, 49-50.

Yang, Q., Zhan, H., Wang, S., Fu, S., \& Li, K. (2007). Biomodification of eucalyptus chemithermomechanical pulp with different white-rot fungi. Bioresource, 2(4), 682-692.

Zadrazil, F., Permana, I. G., \& Wiesche, C. I. (1999). Is the conversion of lignocellulosics into feed with white rot fungi realizable? Practical problems of scale up and Technology transfer. Deutscher Tropentag 1999 in Berlin Session: Sustainable Technology Development in Animal Agriculture. Braunschweig, Germany: Institut für Pflanzenernährung und Bodenkunde, Bundesforschungsanstalt für Landwirtschaft. 